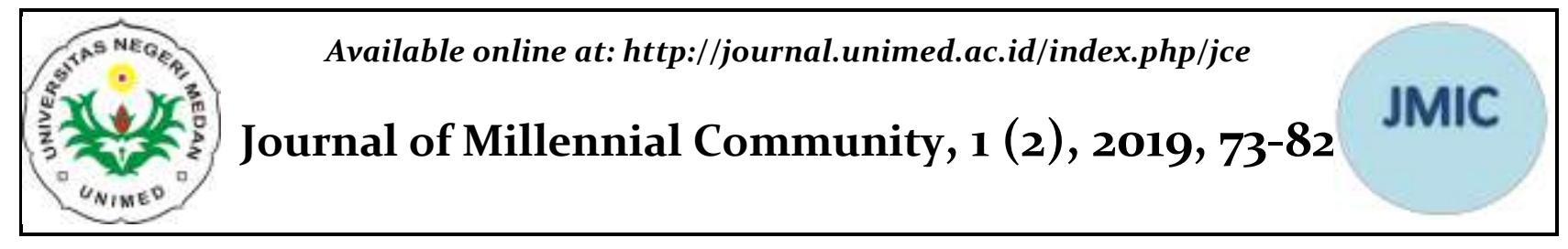

\title{
Implementasi Program Keaksaraan Fungsional Untuk Meningkatkan Motivasi Belajar Warga Binaan Lapas Wanita Di Tanjung Gusta Medan
}

\author{
Cut Wilda Lubis ${ }^{1}$, Rosdiana ${ }^{2}$ \\ 12 Universitas Negeri Medan \\ Opiniunimed@gmail.com
}

\begin{abstract}
Abstrak
Penelitian ini bertujuan untuk;(1) mengetahui gambaran tentang pelaksanaan program keaksaraan fungsional terhadap motivasi belajar warga binaan di Lapas wanita Tanjung Gusta Medan, (2) mengetahui motivasi belajar warga binaan di Lapas wanita Tanjung Gusta Medan, dan (3) mengetahui pengaruh pelaksanaan program keaksaraan fungsional terhadap motivasi belajar warga binaan di Lapas wanita Tanjung Gusta Medan. Jenis penelitian ini menggunakan metode kuantitatif. Sampel penelitian ini berjumlah 60 warga binaan di lapas wanita Tanjung Gusta Medan. Alat pengumpulan data menggunakan angket, Teknik analisis data menggunakan rumus Regresi Linier Serhana. Hasil penelitian menunjukkan bahwa pelaksanaan program keaksaraan fungsional berpengaruh terhadap motivasi belajar warga binaan di lapas wanita Tanjung Gusta Medan, Motivasi belajar warga binaan di lapas wanita Tanjung Gusta Medan ( $\mathrm{Y}$ ) sebesar 68\% dipengaruhi oleh pelaksanaan program keaksaraan fungsional sedangkan sisanya $32 \%$ disebabkan faktor lain yang tidak termasuk dalam analisis ini.
\end{abstract}

Kata Kunci: Pembelajaran, Buta aksara, Motivasi belajar, Lapas wanita

\section{The Effect of the Implementation of Illiteracy Learning on Learning Motivation of Assisted Residents in Tanjung Gusta Women's Prison in Medan}

\begin{abstract}
This study aims to: (1) find a picture of the implementation of illiteracy learning towards the learning motivation of fostered citizens in the Tanjung Gusta Women's Prison in Medan, (2) know the motivation to learn the fostered people in the Tanjung Gusta Women's Prison in Medan, and (3) find out the effect of the learning implementation illiterate to the learning motivation of fostered residents in Tanjung Gusta Women's Lapas Medan. This type of research uses quantitative methods with a clause approach (cause and effect). The sample of this study was 60 fostered residents in the Tanjung Gusta women's prison in Medan. Data collection tools using a questionnaire, data analysis techniques using the Serhana Linear Regression formula. The results showed that the implementation of illiterate learning affected the motivation of fostered learning in the Tanjung Gusta Women's Prison in Medan, it is known from the calculation results obtained tcount $>$ ttable is 39.15>1.671. The motivation of learning fostered citizens in the Tanjung Gusta women prison in Medan $(Y)$ by $68 \%$ is influenced by the implementation of illiteracy learning while the remaining $32 \%$ is due to factors others that are not included in this analysis.
\end{abstract}

Keywords: Learning, illiteracy, learning motivation, women's prison 


\section{PENDAHULUAN}

Di era modern seperti sekarang ini, banyak kendala yang harus di hadapi untuk dapat memperoleh pendidikan yang tinggi. Salah satu dari kendala itu adalah besarnya biaya yang harus di keluarkan untuk mengayom pendidikan. Banyak orang-orang yang berkeinginan untuk melanjutkan pendidikan tetapi mereka terpaksa menyurutkan keinginannya karena kekurangan biaya. Oleh karena itu pemerintah mengadakan program pendidikan yang dapat membantu masyarakat untuk mengecap pendidikan yang dilaksanakan melalui tiga jalur yaitu : formal , informal dan nonformal (Sudjana, 2001).

Dalam pendidikan non formal atau disebut dengan pendidikan luar sekolah ada beberapa program didalamnya, salah satunya yaitu pendidikan keaksaraan. Pendidikan keaksaraan merupakan bentuk layanan program pendidikan nonformal yang ditujukan bagi komunitas khusus melalui proses pembelajaran dan pelatihan dalam rangka pemberdayaan masyarakat agar memiliki kemampuan membaca, menulis, dan berhitung sehingga mampu mencari dan mengelola informasi serta memecahkan masalah yang dihadapi dalam kehidupan sehari hari. Pendidikan keaksaraan juga bertujuan untuk mengatasi masyarakat yang buta aksara, karena dalam kenyataannya masih banyak warga Negara yang buta aksara (Kusnadi, 2001).

Salah satu lembaga pemerintah yang mengadakan program keaksaraan fungsional adalah SKB (Sanggar Kegiatan Belajar), dan salah satunya adalah SKB Medan, dalam penyelenggaraan program keaksaraan fungsional, SKB Medan bekerja sama dengan Lembaga Pemasyarakatan Tanjung Gusta Medan (Irwan,M, 2017). Di lembaga Pemasyarakat (Lapas) merupakan tempat binaan orang - orang mengalami pemikiran-pemikiran mengenai fungsi Pemasyarakatan tidak lagi sekedar penjeraan tetapi juga merupakan suatu usaha rehabilitasi dan reintegrasi sosial
Warga Binaan Pemasyarakatan telah melahirkan suatu sistem pembinaan yang di namakan dengan sistem pemasyarakatan (Abadulhak,2000)(Kahar, 2019).

Pada tanggal 27 April 1964 dalam Page $\mid 74$ Konferensi Jawatan Kepenjaraan yang dilaksanakan di Lembaga Pemasyarakatan Bandung dilakukan sebagai pengganti kepenjaraan. Lembaga Pemasyarakatan dalam Konferensi ini dinyatakan sebagai suatu sistem Pembinaan terhadap para pelanggar Hukum dan sebagai suatu pengejawantahan keadilan yang bertujuan untuk mencapai reintegrasi social atau pulihnya kesatuan hubungan Warga Binaan Pemasyarakatan dengan masyarakat. Dalam pengembangan selanjutnya, pelaksanaan sistem Pemasyarakatan yang telah dilaksanakan sejak tahun 1964 semakin mantap dengan diundangkannya Undang-Undang Nomor 12 Tahun 1995 Tentang Lembaga Pemasyarakatan.

Dengan Undang-Undang Pemasyarakatan ini maka makin kokoh usaha -usaha dalam mewujutkan suatu sistem Pemasyarakatan. Sebagai tatanan mengenai arah dan batas serta cara Pembinaan Warga Binaan Pemasyarakatan berdasarkan Pancasila yang dilaksanakan secara terpadu antara Pembina, yang dibina dan masyarakat untuk meningkatkan kualitas-kualitas Warga Binaan Pemasyarakatan. Agar WBP memperbaiki diri dan tidak mengulangi tindak pidana sehingga dapat diterima kembali oleh lingkungan masyarakat, dapat aktif berperan dalam pembangunan dan dapat hidup secara wajar sebagai warga negara yang baik dan bertanggung jawab.

Dalam penyelenggaraan program ini, semua warga belajar diharapkan dapat memperoleh pengetahuan dan menguasai keterampilan membaca , menulis, berhitung (calistung) dan keterampilan fungsional lain yang bermanfaat bagi warga belajar (Bawani, I., \& Fauziyah, 2014). Kemampuan calistung ini dapat dibuktikan dengan hasil pelaksanaan 
evaluasi atau penilaian harian oleh tutor dan evaluasi akhir program (Wulandari, 2018). Tes ini meliputi penilaian terhadap kemampuan dan penguasaan membaca, menulis, dan berhitung. Program ini bertujuan untuk mengembangkan kemampuan dalam menguasai dan menggunakan keterampilan membaca, menulis, berhitung, mengamati, dan menganalisis kehidupan sehari-hari dan memanfaatkan potensi yang ada di lingkungannya, sehingga masyarakat dapat berpartisipasi dalam pembangunan. Secara khusus bertujuan agar warga belajar dapat menggunakan keterampilan membaca, menulis, dan berhitung untuk memecahkan masalah kehidupan seharihari dan dapat mencari jalan dalam mencari sumber-sumber pendapatan serta dapat senantiasa belajar dan mempelajari kehidupan (Bloom, 2005).

Pelaksanaan program keaksaraan fungsionalmerupakan seperangkat rencana yang akan dilaksanakan dalam rangka memncapai tujuan. Kegiatan pembelajaran tersebut agar berjalan dengan baik maka dapat diterapkan sesuai rencan yang telah diteteapkan. Dimana program keaksaraan fungsionalmerupakan kemampuan untuk menggunakan bahasa dan menggunakannya untuk mengerti sebuah bacaan, mendengarkan perkataan, mengungkapkannya dalam bentuk tulisan, dan berbicara (Hapsari, s, 2018). Kemampuan baca, tulis dianggap penting karena melibatkan pembelajaran berkelanjutan oleh seseorang sehingga orang tersebut dapat mencapai tujuannya, dimana hal ini berkaitan langsung bagaimana seseorang mendapatkan pengetahuan, menggali potensinya, dan berpartisipasi penuh dalam masyarakat yang lebih luas (Fikri, 2010), (Hartono, 2010). Pelaksanaan program keaksaraan fungsional bertujuan untuk meningkatkan motivasi belajar, pembelajaran lebih menarik, dan warga belajar dapat lebih lama mengingat pesan yang diterima,lebih termotivasi dalam belajar. Dengan peningkatan kualitas belajar pada tingkat yang maksimal, warga belajar lebih senang terhadap mengikuti pembelajaran buta aksara, dapat menambah motivasi dan hasil belajarnya, menambah motivasi untuk berpikir dan belajar sendiri dalam pembelajaran calistung.

Namun kenyataan menunjukkan bahwa tidak semua pelaksanaan terlaksana dengan baik karena beberapa sebab dapat lihat di lokasi lembaga pemasyarakatan tersebut pelaksanaan program keaksaraan fungsional ini tidak digunakan secara maksimal dalam proses kegiatan pembelajaran. Banyak faktor penyebab ketidakberhasilan dalam pelaksanaan tersebut antara lain manajemen yang buruk dari pengelola (Erilantu, G, 2016),pembagian tugas para pelaksana yang tidak jelas, displin yang rendah, Motivasi warga binaan yang rendah, Kemampuan tutor rendah, tutor kurang bervariasi dalam gaya menguasai materi dan kurang memperhatikan warga binaan dalam mengikuti kegiatan pembelajaran sehingga warga binaan kurang memperhatikan kegiatan pembelajaran tersebut. kurangnya motivasi warga binaan dalam mengikuti kegiatan pembelajaran tersebut, Sarana dan Prasarana tidak memadai. Berdasarkan hasil pengamatan dan diskusi dengan tutor, bahwa proses penyampaian pesan pada lembaga pemasyarakatan dominan hanya menggunakan metode konvensional (ceramah dan pemberian tugas), bahkan media yang digunakan hanya papan tulis dan buku pedoman untuk bahan ajar tersebut, Tetapi buku pedoman tersebut tidak dipergunakan.Tutor hanya mengajarkan materi tentang huruf-huruf, angka-angka, kurang-kurang dan tambah-tambah kemudian warga binaan memperhatikan sambil menulisnya kembali.Tutor menyuruh kembali warga binaan mengerjakan dan menjumlahkan bahan materi yang ada di papan tulis tersebut, Dalam hal ini membuat warga binaan merasa cepat merasa bosan. Untuk mengatasi rasa kebosanan tersebut, warga binaan biasanya mengganggu warga belajar lainnya seperti ribut sehingga mengakibatkan suasana belajar 
tidak nyaman dan tidak konsentrasi dalam belajar. Warga belajar ada yang bercerita - cerita dengan warga binaan yang lain dan mencari kesibukan lainnya yang tidak berhubungan dengan apa yang dipelajari, dan ada juga warga binaan yang tidak memiliki minat dan bakat dalam memahami dan menerima kegiatan program keaksaraan fungsionaltersebut.

Warga belajar hanya menginginkan sertifikasi, namun kenyataannya warga belajar tidak tahu apa fungsi serifikasi tersebut dalam kebutuhan mereka karena warga belajar belum memahami pelaksanaan program keaksaraan fungsionaldalam kehidupan mereka dalam mengikuti kegiatan program keaksaraan fungsionaltersebut dan sasarannya berusia 14 tahun keatas (Muhamad, 2007).

$$
\text { Seharusnya tutor dalam }
$$

menyampaikan bahan materi harus menguasai, memiliki gaya yang bervariasi dan memperhatikan warga binaan dalam melakukan kegiatan pembelajaran tersebut, sehingga warga binaan tidak merasakan kebosanan dalam mengikuti kegiatan pembelajaran. Kemudian warga binaan merasakan pun memiliki keseriusan dan mendapatkan motivasi dalam mengikuti kegiatan pembelajaran, Sehingga tutor tersebut merasakan kesenangan dalam melakukan kegiatan pembelajaran tersebut. Maka dalam melaksanakan Pendidikan Setiap warga negara yang berusia tujuh sampai dengan lima belas tahun wajib mengikuti pendidikan dasar (Pasal 6 UU No. 20 tahun 2003). Berdasarkan hasil sensus kependudukan Sumatera Utara tahun 2010, persentase penduduk 7-15 tahun yang belum/tidak sekolah sebesar 2,08 persen dan yang tidak sekolah lagi sebesar 4,85 persen. Ukuran atau indikator untuk melihat kualitas sumber daya manusia (SDM) terkait dengan pendidikan antara lain pendidikan yang ditamatkan dan buta aksara.

Berdasarkan hasil (sensus 2010), persentase penduduk 5 tahun yang berpendidikan minimal tamat SMP/Sederajat sebesar 49,36 persen, dan penduduk berusia 15 tahun ke atas sebesar 96,57 persen yang berarti dari setiap 100 penduduk usia 15 tahun ke atas ada 97 orang yang melek huruf. Penduduk dikatakan melek huruf jika dapat membaca dan menulis huruf latin atau huruf lainnya. Hasil pengamatan sensus Provinsi Sumatera Utara Sementara Pelaksanaan program keaksaraan fungsionaltersebut belum berhasil menurunkan besarnya angka dimana penduduk usia 15 tahun ke atas sebesar 99,09 persen. Penduduk usia 15 tahun ke atas perempuan (98,64 persen) lebih rendah dibandingkan laki-laki $(99,53$ persen) (Akhrurozi,2002). Penduduk usia 15 tahun ke atas di daerah perdesaan $(100,00$ persen) lebih rendah dibandingkan daerah perkotaan $(99,09$ persen). Rendahnya penduduk usia 15 tahun ke atas disebabkan oleh rendahnya buta aksara penduduk usia 45 tahun ke atas. Penduduk usia 45 tahun ke atas sebesar 97,29 persen. Penduduk usia 45 tahun ke atas perempuan (95,81 persen) lebih rendah dibandingkan laki-laki $(98,77$ persen), Sehingga sampai saat ini buta aksara tetap saja masih tinggi. Pelaksanaan program keaksaraan fungsionaljuga sangat terkait dengan kemiskinan,keterbelakangan,kebodohan, dan ketidakberdayaan masyarakat. Sehingga permasalahan buta aksara ini tidak saja menjadi permasalahan nasional tetapi sudah diangkat menjadi permasalahan internasional. Untuk mengetahui sejauhmana keberhasilan pelaksanaan kegiatan buta aksara,Maka perlu adanya evaluasi.Melalui evaluasi pelaksanaan diharapkan dapaat diketahui berbagai informasi tentang prosess pelaksanaan dan hasil yang akan dicapai

\section{METODE}

Penelitian ini menggunakan jenis penelitian kuantitatif dengan pendekatan kausal (sebab akibat) karena dianggap variabel yang mempengaruhi dan dipengaruhi tepat untuk meneliti Pengaruh Pelaksanaan Program keaksaraan fungsionalTerhadap Motivasi Belajar Warga Binaan Pada Lembaga 
Pemasyarakatan Tanjung Gusta Medan. Populasi dalam penelitian ini adalah 120 orang warga belajar yang ada di dalam lembaga pemasyarakat. Populasi dalam penelitian ini adalah keseluruhan warga belajar binaan lapas wanita yang berjumlah 120 orang. Dalam menentukan sampel penulis mengutip pernyataan Arikunto (2006:134) yang menyatakan bahwa: " apabila subjeknya kurang dari 100 orang,lebih baik diambil sehingga penelitiannya merupakan populasi, selanjutnya jika subjeknya besar dapat diambil antara $10-15 \%$ atau $20-25 \%$ atau lebih,tergantung dari :

a. Kemampuan peneliti dari waktu dan tenaga

b. Sampel luas wilayah pengamatan dari subyek karena hal ini menyangkut banyak atau sedikitnya data

c. Besar kecilnya resiko yang ditanggung peneliti

Berdasarkan ketentuan tersebut maka sampai dalam penelitian ini ditentukan sebanyak $50 \%$ atau $120 \times 50$ $\%=60$. Dengan kata lain sampel ini merupakan respon dari orang-orang yang menjawab atau dimintai untuk mengisi angket.

Sejumlah pertanyaan yang diajukan kepada responden untuk memperoleh data dari responden. Dengan kata lain yang berisikan pertanyaan-pertanyaan yang tertulis yang diedarkan kepada responden untuk dijawab secara tertulis sehingga data yang diperlukan dapat diperoleh. Untuk mendukung penelitian, maka penulis menggunakan teknik pengumpulan data dengan angket semi tertutup. Angket disusun oleh peneliti sebanyak 25 pertanyaan mengenai program keaksaraan fungsionaldan mengenai motivasi belajar.

Untuk mengetahui tingkat ketepat instrumen yang dilaksanaka dan untuk pengujian validitas tiap butir angket digunaakan analisis item, yaitu mengkorelasikan skor tiap butir dengan total yang merupakan jumlah tiap skor butir (Sugiyono, 2009: 187). Reliabilitas menujukan bahwa suatu instrument dapat dipercaya untuk digunakan sebagai alat pengumpulan data karena instrument tersebut sudah baik. Reliabilitas disini menunjukan pada tingkat keteladanan suatu instrumen dalam mengumpulkan data serta kemampuan alat ukur tersebut digunakan akan memberikan hasil ukur yang sama.

Data yang digunakan adalah dalam bentuk kuantitatif (berbentuk angkaangka) (Arikunto, S, 2002) Rumus yang digunakan rumus persamaan regresi,uji linieritas dan keberartian regresi linier sederhana,uji linieritas dilakukan untuk mengetahui apakah terdapat pengaruh antara variabel bebas $(X)$ dan variabel terikat $(Y)$ bersifat linier. Uji linieritas dilakukan dengan uji linieritas dan keberartian regresi linier sederhana,melalui persamaan sebagai berikut: $Y=a+b x$ (Sudjana, $2002: 369$ )

\section{PEMBAHASAN}

Pelaksanaan program keaksaraan fungsionalbagi warga binaan di Lapas Wanita Tanjung Gusta Medan dengan materi calistung dilaksanakan 2 kali dalam seminggu yaitu senin dan selasa dari jam $10.00 \mathrm{~s} / \mathrm{d}$ 13. Namun kenyataan diketahui tidak semua pelaksanaan terlaksana dengan baik, disebabkan kemampuan tutor yang rendah dalam penguasaan materi, dan metode mengajar yang cendrung menggunakan metode ceramah. Tutor hanya mengajarkan materi tentang huruf-huruf, angka-angka, kurang-kurang tambah-tambah kemudian warga binaan memperhatikan sambil menulisnya kembali. Tutor menyuruh kembali warga binaan mengerjakan dan menjumlahkan bahan materi yang ada di papan tulis tersebut. Hal ini menyebabkan warga binaan merasa cepat bosan dan pelampisan rasa kebosanan tersebut mereka lampiaskan untuk menganggu teman-teman yang lagi serius dalam belajar sehingga mengakibatkan suasana belajar menjadi tidak kondusif. 
Sebagian warga binaan kurang termotivasi dalam kegiatan program keaksaraan fungsionalkarena mereka belum sepenuhnya memahami betapa pentingnya program buta aksara sebagai bekal keterampilan bagi mereka, bahkan ada warga binaan yang hanya menginginkan sertifikat sebagai tanda pengakuan bahwa dia tidak buta aksara lagi sehingga program yang diharapkan tidak sesuai dengan kenyataan. Akan tetapi ada juga warga binaan yang memiliki motivasi yang baik untuk selalu aktif mengikuti pelaksanaan pembelajaran buta aksara, hal ini dapat dilihat dari keseriusan warga binaan mengikuti kegiatan yang dilaksanakan, seperti memperhatikan dengan serius ketika tutor menyampaikan materi pelajaran, bertanya terhadap materi yang kurang dipahami dan menjawab pertanyaan yang diajukan tutor. Ini membuktikan bahwa kesadaran tutor akan arti penting program buta aksara dalam meningkatkan keterampilan dapat dikatakan baik.

Pada dasarnya ada pengaruh pelaksanaan program keaksaraan fungsionalterhadap motivasi belajar warga binaan di Lapas Wanita Tanjung Gusta Medan, hal ini dapat dilihat dari meningkatnya potensi warga binaan terhadap dirinya seperti peningkatan pengetahuan, keterampilan dan kemandirian. Sehingga ketika mereka kembali kemasyarakat, tentunya sudah memiliki keterampilan yang memadai dan dengan dimilikinya keterampilan dipastikan akan mampu berkompetensi dengan masyarakat umumnya.

\section{Pelaksanaan Pembelajaran Buta Aksara}

Hasil perhitungan data pelaksanaan program keaksaraan fungsionaldi lapas wanita Tanjung Gusta Medan yang diperoleh dapat dilihat pada tabel 1 berikut:

Tabel 1. Pelaksanaan Program keaksaraan fungsionalDi Lapas Wanita Tanjung Gusta Medan

\begin{tabular}{ccc}
\hline $\begin{array}{c}\text { Jumlah } \\
\text { Responden }\end{array}$ & $\%$ & Kategori \\
\hline 55 & 91,7 & Rendah \\
5 & 8,3 & Sedang \\
0 & - & Tinggi \\
\hline
\end{tabular}

Page $\mid 78$

Berdasarkan tabel 1, diketahui 55 responden menyatakan pelaksanaan program keaksaraan fungsionaldalam kategori rendah disebabkan rendahnya kemampuan tutor dalam penguasaan materi pelajaran yang disampaikan, metode mengajar yang monoton karena cendrung menggunakan metode ceramah, bahkan tutor jarang sekali menggunakan media pembelajaran yang sesuai dengan materi yang diajarkan. Selanjutnya 5 responden menyatakan pelaksanaan program keaksaraan fungsionaldalam kategori sedang, hal ini dikarenanya karena warga binaan memiliki keinginan yang kuat untuk bisa membaca, menulis dan berhitung, sehingga ketika program keaksaraan fungsionaldilaksanakan, mereka selalu serius mengikutinya. mereka selalu termotivasi mengikuti kegiatan yang dilaksanakan. Jika dikonsultasikan kategori pelaksanaan program keaksaraan fungsionaldengan nilai rata-rata $=24,06$ dalam kategori rendah karena berada dalam rentang skor 15-30.

\section{Motivasi Belajar Warga Binaan Di Lapas Wanita Tanjung Gusta Medan}

Hasil perhitungan data motivasi belajar warga binaan di lapas wanita Tanjung Gusta Medan yang diperoleh dapat dilihat pada tabel berikut:

Tabel 2. Motivasi Belajar Warga Binaan Di Lapas Wanita Tanjung Gusta Medan

\begin{tabular}{ccc}
\hline $\begin{array}{c}\text { Jumlah } \\
\text { Responden }\end{array}$ & $\%$ & Kategori \\
\hline 10 & 16,7 & Rendah \\
42 & 70 & Sedang \\
8 & 13,3 & Tinggi \\
\hline
\end{tabular}


Berdasarkan tabel 2 diketahui 10 responden menyatakan motivasi belajar warga binaan di lapas wanita tanjung Gusta Medan dalam kategori rendah, sebagian warga binaan hanya menginginkan sertifikat sebagai tanda pengakuan bahwa dia tidak buta aksara lagi sehingga progam yang diharapkan tidak sesuai dengan kenyataan, ada juga karena kurangnya pengetahuan warga binaan tentang kegiatan buta aksara hal ini dapat dilihat ketidak seriusan warga binaan untuk mengikuti kegiatan yang dilaksanakan, seperti tidak pernah bertanya terhadap materi yang kurang dipahami, tidak memperhatikan materi yang disampaikan tutor dan lain sebagainya. Selanjutnya diketahui 42 responden menyatakan motivasi belajar warga binaan di lapas wanita tanjung Gusta Medan dalam kategori sedang, hal ini dibuktikan dari keseriusan mengikuti program yang dilaksanakan. Ini terwujud karena warga binaan memiliki keinginan yang kuat untuk bisa membaca, menulis dan berhitung. Jika dikonsultasikan kategori motivasi belajar warga binaan dengan nilai rata-rata yang ada yakni 26,35 diketahui bahwa motivasi belajar warga binaan di Lapas Wanita Tanjung Gusta Medan dalam kategori sedang karena berada dalam rentang skor 21-31.

Pelaksanaan program keaksaraan fungsionalbagi warga binaan di Lapas Wanita Tanjung Gusta Medan belum sepenuhnya terlaksana dengan baik, hal ini dikarenakan rendahnya kemampuan tutor dalam penguasaan materi, metode mengajar yang monoton dan kurangnya pemanfaatan media yang sesuai dengan materi yang disampaikan

Motivasi belajar warga binaan dalam kategori sedang, hal ini dapat dilihat dari keseriusan warga binaan mengikuti kegiatan yang dilaksanakan, seperti memperhatikan dengan serius ketika tutor menyampaikan materi pelajaran, bertanya terhadap materi yang kurang dipahami dan menjawab pertanyaan yang diajukan tutor. Ini membuktikan bahwa kesadaran tutor akan arti penting program buta aksara dalam meningkatkan keterampilan dapat dikatakan baik.

Ada pengaruh pelaksanaan program keaksaraan fungsionalterhadap motivasi belajar warga binaan di Lapas Wanita Tanjung Gusta Medan, hal ini dapat dilihat dari pengujian hipotesis dilakukan dengan menggunakan regresi linier sederhana. Dari hasil perhutungan diketahui persamaan regresinya adalah $\hat{Y}=114,4+0,96 X$.

Dengan memperhatikan persamaan tersebut, maka diketahui ada pengaruh pelaksanaan program keaksaraan fungsionalterhadap motivasi belajar warga binaan di lapas wanita Tanjung Gusta Medan.

Sedangkan koefisien korelasi pelaksanaan program keaksaraan fungsionalterhadap motivasi belajar warga binaan di lapas wanita Tanjung Gusta Medan dari hasil perhitungan diketahui ada korelasi positif $(R=0,681)$ antara pelaksanaan program keaksaraan fungsional( $Y$ ) dengan motivasi belajar warga binaan $(X)$, berarti semakin baik pelaksanaan program keaksaraan fungsional semakin baik pula motivasi belajar warga binaan di lapas wanita Tanjung Gusta Medan.

Untuk mengetahui apakah pelaksanaan program keaksaraan fungsionalmemiliki pengaruh yang signifikan terhadap motivasi belajar warga binaan di lapas wanita Tanjung Gusta Medan, maka dilakukan pengujian dengan rumus uji dan dari hasil perhitungan diperoleh nilai $t_{\text {hitung }}>t_{\text {tabel }}$ yaitu $39,15>$ 1,671 . Sedangkan besarnya kontribusi pelaksanaan program keaksaraan fungsionalterhadap motivasi belajar warga binaan di lapas wanita Tanjung Gusta Medan dapat dilihat melalui perhitungan determinan diperoleh nilai $\mathrm{D}=68 \%$, artinya meningkatnya motivasi belajar warga binaan di lapas wanita Tanjung Gusta Medan (Y) sebesar $68 \%$ dipengaruhi oleh pelaksanaan program keaksaraan fungsionalsedangkan sisanya
Page $\mid 79$ 
$32 \%$ disebabkan faktor lain yang tidak termasuk dalam analisis ini.

Berdasarkan hasil perhitungan diketahui nilai rata-rata pelaksanaan program keaksaraan fungsionaladalah 24,06, termasuk dalam kategori rendah karena berada dalam rentang skor 15-30. Hal ini terbukti 55 responden menyatakan pelaksanaan program keaksaraan fungsionaldalam kategori rendah dan 5 responden menyatakan pelaksanaan program keaksaraan fungsionaldalam kategori sedang.

Sedangkan nilai rata-rata motivasi belajar warga binaan adalah 26,35, termasuk dalam kategori sedang karena berada dalam rentang skor 21-31. Hal ini terbukti 10 responden memiliki motivasi belajar dalam kategori rendah, 42 responden memiliki motivasi belajar dalam kategori sedang dan 8 responden memiliki motivasi belajar dalam kategori tinggi.

Selanjutnya dari hasil pengujian hipotesis diketahui persamaan regresinya adalah. Artinya ada pengaruh pelaksanaan program keaksaraan fungsionalterhadap motivasi belajar warga binaan di lapas wanita Tanjung Gusta Medan. Adapun koefisien korelasi pelaksanaan program keaksaraan fungsionalterhadap motivasi belajar warga binaan di lapas wanita Tanjung Gusta Medan, adalah ( $R=0,681)$, berarti semakin baik pelaksanaan program keaksaraan fungsional semakin baik pula motivasi belajar warga binaan di lapas wanita Tanjung Gusta Medan.

Pelaksanaan program keaksaraan fungsionalmemiliki pengaruh yang signifikan terhadap motivasi belajar warga binaan di lapas wanita Tanjung Gusta Medan, hal ini diketahui dari hasil perhitungan diperoleh nilai thitung > ttabel yaitu 39,15>1,671. Sedangkan besarnya kontribusi diperoleh nilai $\mathrm{D}=$ $68 \%$, artinya meningkat atau menurunnya motivasi belajar warga binaan di lapas wanita Tanjung Gusta Medan (Y) sebesar $68 \%$ dipengaruhi oleh pelaksanaan pembelajaran buta aksara.

Berdasarkan hasil penelitian menunjukkan bahwa masih kurangnya Page| 80 kemampuan tutor dalam pelaksanaan pembelajaran buta aksara, menentukan metode pembelajaran, merancang penggunaan metode, merancang penggunaan media dan merumuskan rencana evaluasi warga belajar.

Motivasi sebagian warga belajar yang diselenggarakan Lembaga Pemasyarakatan wanita Tanjung Gusta dalam kategori baik, hal ini terjadi karena warga belajar menyadari akan pentingnya calistung sebagai bekal dimasa depan mereka. Namun ada juga ditemukan warga belajar yang kurang termotivasi dalam mengikuti kegiatan pembelajaran buta aksara, warga binaan hanya menginginkan sertifikat sebagai tanda pengakuan bahwa dia tidak buta aksara lagi, warga binaan belum memahami sepenuhnya pentingnya program buta aksara dalam kehidupan mereka.

Materi pelaksanaan program keaksaraan fungsionaldi lapas wanita Tanjung Gusta Medan adalah pembelajaran calistung (membaca, menulis dan berhitung) yang diselenggarakan 2 kali dalam seminggu yaitu senin dan selasa dari pukul $10.00 \mathrm{~s} / \mathrm{d}$ 13.00. Penyampaian materi dengan dua cara yakni secara teori dan praktek.

Sebagian tutor masih menggunakan metode ceramah dan pemberian tugas dalam pembelajaran calistung. Tutor mendominasi pembicaraan sementara warga binaan terpaksa bahkan dipaksa untuk duduk, mendengar dan mencatat, sehingga terlihat ada sebagian warga binaan yang jenuh ketika mengikuti kegiatan ini. Hasil evaluasi ini 
menunjukkan bahwa pelaksanaan program keaksaraan fungsionalyang dilaksanakan belum sepenuhnya berhasil. Ada beberapa indikator yang dapat mempengaruhi kinerja tutor di Lembaga Pemasyarakatan wanita Tanjung Gusta, di antaranya tingkat pendidikan, pengalaman kerja, dan motivasi.

Salah satu upaya untuk melakukan pemberantasan buta huruf, dengan mengaktifkan perpustakaan di Rutan dan adanya ruang kelas, sehingga warga binaan diharapkan lebih termotivasi untuk serius dalam pelaksanaan program keaksaraan fungsionalyang selama ini dilaksanakan.

Untuk meningkatkan hasil belajar warga binaan di Lapas Tanjung Gusta Medan saat ini telah dilaksanakan Program Pemberantasan Buta Aksara dengan pendekatan keaksaraan fungsional. Program ini dimaksudkan untuk menumbuhkan motivasi internal dari warga binaan. Keaksaraan fungsional merupakan pendekatan atau cara untuk mengembangkan kemampuan warga binaan dalam menguasai dan menggunakan keterampilan membaca, menulis dan berhitung (calistung) yang didasarkan pada kebutuhan, minat, pengalaman hidup sehari-hari serta memanfaatkan potensi yang ada di lingkungan sekitarnya.

Peran tutor tidak hanya pada proses pembelajaran calistung akan tetapi mulai dari merencanakan kegiatan belajar, mengidentifikasi minat dan kebutuhan warga binaan, menyusun kurikulum bersama warga binaan, mencari bahan belajar sekaligus menyesuaikan dengan kemampuan warga binaan dan mengevaluasi proses pembelajaran yang partisipatif. Pembelajaran keaksaraan fungsional melibatkan warga binaan mulai dari perencanaan program belajar sampai dengan penilaian hasil belajar.

\section{KESIMPULAN}

Pelaksanaan program keaksaraan fungsional berpengaruh terhadap motivasi belajar warga binaan di lapas wanita Tanjung Gusta Medan. Artinya keaksaraan fungsional berpengaruh terhadap motivasi Page | 81 belajar warga binaan di lapas wanita Tanjung Gusta Medan. Koefisien korelasi pelaksanaan program keaksaraan fungsional berpengaruh terhadap motivasi belajar warga binaan di lapas wanita Tanjung Gusta Medan. sebesar $R=0,681$, artinya semakin baik pelaksanaan program keaksaraan fungsional semakin baik pula motivasi belajar warga binaan di lapas wanita Tanjung Gusta Medan. Pelaksanaan program keaksaraan fungsional memiliki pengaruh yang signifikan terhadap motivasi belajar warga binaan di lapas wanita Tanjung Gusta Medan, hal ini diketahui dari hasil perhitungan diperoleh nilai $t_{\text {hitung }}>t_{\text {tabel }}$ yaitu 39,15>1,671. Kontribusi pelaksanaan program keaksaraan fungsionalterhadap motivasi belajar warga binaan di lapas wanita Tanjung Gusta Medan sebesar $=68 \%$, artinya motivasi belajar warga binaan di lapas wanita Tanjung Gusta Medan (Y) sebesar 68\% dipengaruhi oleh pelaksanaan program keaksaraan fungsionalsedangkan sisanya $32 \%$ disebabkan faktor lain yang tidak termasuk dalam analisis ini.

\section{DAFTAR PUSTAKA}

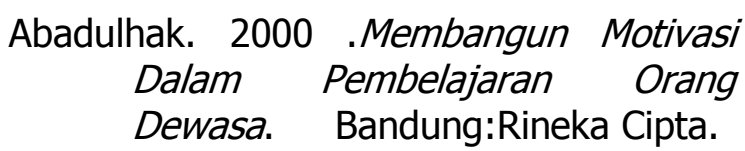

Arikunto, S. 2002. Prosedur Penelitian. Edisi Revisi. Suatu Pendekatan Praktik.Jakarta : Bima Ilmu.

Akhrurozi. 2009. Buta aksara dan Kesejahteraan Rakyat.Jakarta:Bima ilmu.

Bawani, I., \& Fauziyah, N. (2014). Pengelolaan Program Keaksaraan Fungsional untuk Memberantas 
Buta Aksara di Petissari, Babaksari, Dukun, Gresik. Jurnal Kependidikan Islam, 4(1), 56-84.

Blom. 2005 .Aspek-Aspek Intelektual. Jakarta. Rineka cipta

Erilantu, G. (2016). Evaluasi program aksara kewirausahaan anyaman bambu dalam upaya pemberdayaan masyarakat di PKBM Prima Education. JPPM (Jurnal Pendidikan dan Pemberdayaan Masyarakat), 3(2), 165-175.

Fikri. 2010 . Buta Aksara, Empat Lawang Tinggi.Bandung: Usaha Nasional.

Kahar, M. S., Ibrahim, I., Rusdi, A., \& Sukmawati, S. (2019). Pemberdayaan Masyarakat Papua Di Distrik Bikar Kabupaten Tambrauw Melalui Pemberantasan Buta Aksara. CARADDE: Jurnal Pengabdian Kepada Masyarakat, 2(1).

Irwan, M. (2017). Evaluasi program pelatihan keterampilan mengolah limbah kertas semen pada PKBM Cahaya Kota Binjai. JPPM (Jurnal Pendidikan dan Pemberdayaan Masyarakat), 4(2), 121-132.

Hapsari, S. (2018). Model Pendidikan Keaksaraan Fungsional Berbasis Media Pembelajaran Untuk Meningkatkan Kemampuan Berpikir Kreatif Pada Diri Warga Belajar. Jurnal Akrab, 9(1), 90-100.

Hartono. 2010 . Apa Kabar Program Pemberantasan Buta aksara?. Bandung: Media Komputindo.

$\begin{array}{ccc}\text { Kusnadi. } 2001 . & \text { Penerapan } & \text { Metode } \\ \text { REFLECT } & \text { Dalam } & \text { Proses } \\ \text { Pembelajaran } & \text { Kelompok } & \text { Belajar } \\ \text { Keaksaraan } & \text { Fungsional } & \text { (Studi }\end{array}$

Kasus pada Dua Kelompok Belajar).Bandung: Rineka Cipta.

Muhamad. 2007. Berantas Buta Aksara lewat Tutorial Terpadu. Semarang: Rineka Cipta.

Production

Sudjana dan Ahmad. 2002. MediaPengajaran. Bandung: Falah

Sudjana. 2001. Pendidikan Luar Sekolah. Bandung: Falah Production.

Sugiyono . 2009. Metode Penelitian Kuantitatif. Jakarta: Rineka Cipta.

Wulandari, R. (2018). Pemberdayaan aksara masyarakat pedesaan: evaluasi program keaksaraan fungsional pada kelompok "ngudi kawruh" di kelurahan pasar kliwon kota surakarta. CENDEKIA: Jurnal Studi Keislaman, 3(1). 